\title{
Smoke-free home initiative in Bantul, Indonesia: Development and preliminary evaluation
}

\author{
Heni Trisnowati ${ }^{1,2}$, Dian Kusuma ${ }^{3}$, Abdillah Ahsan ${ }^{4}$, Dwi E. Kurniasih ${ }^{5}$, Retna S. Padmawati ${ }^{6,7}$
}

\begin{abstract}
INTRODUCTION Tobacco control policies in Indonesia are still limited. This study aims to describe the process of the implementation of the smokefree home $(\mathrm{SFH})$ program in rural areas in Indonesia and to conduct a preliminary evaluation of its implementation.

METHODS The development of SFH (or Rumah Bebas Asap Rokok) applies the theory of diffusion of innovation with the following stages: innovation, dissemination, adoption, implementation, and evaluation. The preliminary evaluation of the SFH program used an observational method combined with a cross-sectional survey. The population of this study was all houses in Karet hamlet, in Bantul district, Yogyakarta province with 378 houses as population, from which 196 houses were selected as sample using the proportional random sampling technique. Quantitative data analysis used multiple linear regression in Stata 15.1.

RESULTS SFH is a community-based tobacco control innovation program that began with a community declaration. Preliminary evaluation after one-year implementation showed that $55 \%$ and $45 \%$ of respondents were smokers and non-smokers, respectively. Among smokers, 95\%, 78\% and $56 \%$ reported not smoking near pregnant women, children, and nonsmokers, respectively. Moreover, $52 \%$ of respondents reported having a front-door ashtray, and 46\% reported guests not smoking; among nonsmokers, the corresponding values were $56 \%$ and $60 \%$.

CONCLUSIONS SFH implementation has an impact on the community's smoking pattern. Awareness of smokers to protect women and children from secondhand smoke is very high. While the results are promising, more political and resource support is needed from the local and national policymakers to support SFH initiatives.
\end{abstract}

AFFILIATION

1 Division of Health Promotion Program,

Public Health Department, Universitas Respati Yogyakarta, Indonesia

2 Doctoral Program, Faculty of Medicine,

Public Health and Nursing, Universitas Gadjah

Mada, Yogyakarta, Indonesia

3 Centre for Health Economics and Policy Innovations, Imperial College Business School,

London, United Kingdom

4 Faculty of Economy and Business, Universitas Indonesia, Depok, Indonesia

5 Division of Health Policy and Administration

Program, Public Health Department,

Universitas Respati Yogyakarta, Indonesia

6 Department of Health Behavior, Environment and Social Medicine, Faculty of Medicine,

Public Health and Nursing, Universitas Gadjah

Mada, Yogyakarta, Indonesia

7 Center of Health Behavior and Promotion,

Faculty of Medicine, Public Health and

Nursing, Universitas Gadjah Mada, Yogyakarta, Indonesia

\section{CORRESPONDENCE TO}

Heni Trisnowati. Division of Health Promotion Program, Public Health Department,

Universitas Respati Yogyakarta, Indonesia.

E-mail: heni_trisnowati@respati.ac.id ORCID

ID: https://orcid.org/0000-0002-4621-5205

\section{KEYWORDS}

secondhand smoke, smoke-free home, rural area, smoke-free environment, preliminary evaluation

Received: 31 May 2019

Revised: 15 October 2019

Accepted: 24 October 2019

\section{INTRODUCTION}

Tobacco use is the world's leading cause of death that can be prevented ${ }^{1}$. One in ten deaths globally is caused by tobacco use ${ }^{2}$. If the trend continues, it would be responsible for more than 8 million deaths per year worldwide by 2030 , of which $80 \%$ will occur in low- and middle-income countries (LMICs) $^{3}$. In Indonesia, $56 \%$ of males and $2 \%$ of females, aged $\geq 10$ years, were smokers in 2018 , indicating very high exposure to secondhand smoke $(\mathrm{SHS})^{4}$. The Global Adults Tobacco Survey (GATS) reported that $78 \%$ of adults were exposed to SHS 
at home in $2011^{5}$. Exposure to SHS increases the risk of cardiovascular diseases, respiratory diseases, and lung cancer, especially among the most vulnerable populations such as children and pregnant women ${ }^{6-7}$.

Tobacco control policies are still limited in Indonesia, the only country in the Asia Pacific region that has not ratified the Framework Convention on Tobacco Control (FCTG) ${ }^{2}$. While the tobacco industry is proliferating in the midst of minimal antismoking policies and regulations ${ }^{8}$, efforts are needed at the regional, district and village levels. The smokefree home ( $\mathrm{SFH})$ initiative is a bottom-up effort to control smoking by involving the community directly with the primary goal of protecting nonsmokers. Reducing the exposure to SHS, especially among women and children, is a significant public health challenge ${ }^{9,10}$. The SFH initiative has been developed in several countries, but the results vary. Experiences in high-income countries show that $\mathrm{SFH}$ is an effective means of reducing levels of cigarette consumption and increasing the likelihood of quitting smoking ${ }^{11-13}$. Experiences in LMICs such as India and Indonesia, especially in urban areas, indicate that the SFH initiative reduces smoking behaviour in homes and increases smokers' readiness to stop smoking ${ }^{14-16}$. This study describes the efforts to develop an $\mathrm{SFH}$ initiative in rural settings in Bantul district, Indonesia, and provides a preliminary evaluation.

\section{METHODS}

The development of SFH in Bantul (or Rumah Bebas Asap Rokok) applies the theory of diffusion of innovation with the following stages: innovation, dissemination, adoption, implementation, and evaluation. The evaluation used an observational method with a cross-sectional questionnaire survey. The population of this study was all houses in Karet hamlet, in Bantul district, Yogyakarta province with 378 houses as population, from which 196 houses were selected as sample using the proportional random sampling technique. Quantitative data analysis in Stata 15.1 employed multiple linear regression controlling for age, income, and having children. Ethical clearance was obtained from the ethics committee of the University of Respati Yogyakarta (No.236.3/UNRIYO/PL/XI/2018).

\section{RESULTS}

Table 1 summarizes the development of the SFH initiative in Bantul (more details are given in the Supplementary file). In the first stage, Innovation Development, a need assessment was carried out to obtain preliminary data related to community smoking habits through surveys, interviews with community leaders, and stakeholders. Before the program, 90\% of smokers were willing to smoke outside the home. Almost all residents agreed not to smoke inside the home. The next activity was the Village Community Deliberation with community leaders and health

Table 1. Development stages of the SFH initiative, Indonesia

\begin{tabular}{|c|c|c|}
\hline Stage & Activity & Duration \& number of villages \\
\hline $\begin{array}{l}\text { Innovation } \\
\text { development }\end{array}$ & $\begin{array}{l}\text { - Need assessment: survey smoking behaviour among communities in a village, } \\
\text { interview with stakeholders } \\
\text { - Village Community Deliberation with community leaders and health centre } \\
\text { staff }\end{array}$ & $\begin{array}{l}2 \text { months } \\
\text { (January-February 2017) } \\
1 \text { Village } \\
\text { ( } 378 \text { households or } 8 \text { RT) }\end{array}$ \\
\hline Dissemination & $\begin{array}{l}\text { - Regular meetings with a community group through socialization and } \\
\text { education } \\
\text { - Installation of SFH stickers in front of residents' house } \\
\text { - installation of 'cecekan' (front-door ashtray) }\end{array}$ & $\begin{array}{l}2 \text { months } \\
\text { (March-May 2017) } \\
1 \text { Village }\end{array}$ \\
\hline Adoption & $\begin{array}{l}\text { The community has given a positive response to the SFH initiative and } \\
\text { conducted declaration }\end{array}$ & $\begin{array}{l}1 \text { month } \\
\text { (May-June 2017) } \\
1 \text { Village }\end{array}$ \\
\hline Implementation & $\begin{array}{l}\text { - House has front-door ashtray } \\
\text { - Guest not smoking at home } \\
\text { - Smoker does not smoke near family } \\
\text { - Smoker not smoking near children, pregnant women, and non-smokers } \\
\text { - Smokers do not smoke at community meetings }\end{array}$ & $\begin{array}{l}6 \text { months or sooner } \\
\text { (June 2017-November 2018) }\end{array}$ \\
\hline
\end{tabular}

RT: Rukun Tetangga or Neighbourhood Association. 
center officers to share the research findings and plan a follow-up in the form of an SFH program.

The second stage, Dissemination, was to sensitise the targeted groups in the community on the $\mathrm{SFH}$ initiative. It was carried out through meetings with fathers, mothers, and youth groups. The SFH activities that were carried out included: 1) education about the dangers of smoking on health using movies and the measurements of blood pressure and blood sugar in the father meetings; 2 ) installation of stickers ('Stub out cigarettes before entering the house'); 3 ) provide a 'cecekan' (frontdoor ashtray) outside the home throughout the community. The aim was for guests or families not to smoke inside the home.

The third stage, Adoption, was when the community responded positively, as shown by the SFH declaration. The declaration was signed by the hamlet head, youth organisations, and community leaders as representatives of the community. The declaration content included not smoking in the house; not smoking near pregnant women, children, and non-smokers; not smoking in community meetings, and installing a front-door ashtray. The declaration was made on 14 June 2017, one year before our preliminary evaluation (November 2018).

The fourth stage, Implementation, was when the community starts applying the content of the SFH declaration. The implementation depends on public awareness on the benefits of $\mathrm{SFH}$ and the support of available resources. During this stage, a preliminary evaluation was carried out to assess the implementation. Before the evaluation was conducted, an interview with community leaders showed that they were supportive and highly motivated to continue SFH towards realising a healthy and smoke-free village. A quote by the village leader: '... this village received the $M D G$ Award in the field of nutrition in 2015, so we want to maintain that achievement with other efforts by implementing smoke-free houses, people who smoke should not be allowed in the house...'.

One implementation challenge was that there were no clear sanctions for non-compliance with the contents of the SFH declaration. The implementation relied mainly on community awareness. Residents generally felt embarrassed if they were found to violate the declaration. Strengthening the sustainability of the program depends on the support of local leaders that are currently positive.

Smokers constituted 55\% $(n=108)$ of the study population. All the respondents were males with an average age of 44.7 years, and $85 \%(n=166)$ reported having children. Also, 51\% $(n=103)$ of respondents were in the first and second lower quintiles of income (i.e. more deprived), $18 \%$ in the third quintile, $15 \%$ in the 4 th quintile and $13 \%$ in the highest income quintile.

Table 2 provides the behaviours related to smoking, one year after the $\mathrm{SFH}$ declaration. Results show that $55 \%$ and $45 \%$ of respondents were smokers and nonsmokers, respectively. Among smokers, 95\%, 78\% and $56 \%$ reported not smoking near pregnant women, near children, or near non-smokers, respectively. Moreover, among smokers $52 \%$ and $46 \%$ reported having a front-door ashtray and guests not smoking;

Table 2. Proportion of respondents who engage in smoking related behaviors in Karet village, Bantul District, 2018

\begin{tabular}{|c|c|c|c|c|c|c|c|c|}
\hline & \multicolumn{2}{|c|}{$\begin{array}{l}\text { Overall } \\
(\mathrm{n}-196)\end{array}$} & \multicolumn{2}{|c|}{$\begin{array}{l}\text { Non-smokers } \\
\text { (n-88) }\end{array}$} & \multicolumn{2}{|c|}{$\begin{array}{l}\text { Smokers } \\
(\mathbf{n}-108)\end{array}$} & \multicolumn{2}{|c|}{ Dilference } \\
\hline & Vean & SD & Vean & SD & Vean & SD & Vean & $p$ \\
\hline & {$[1]$} & & $|2|$ & & $|3|$ & & $|1||23|$ & $|5|$ \\
\hline House has 'Cecekan' (front-door ashtray) & 0.54 & $(0.50)$ & 0.56 & $(0.50)$ & 0.52 & $(0.50)$ & 0.04 & 0.456 \\
\hline Guests not smoking & 0.53 & $(0.50)$ & 0.60 & $(0.49)$ & 0.46 & $(0.50)$ & 0.14 & 0.006 \\
\hline No family members smoking at gatherings & 0.81 & $(0.40)$ & 1.00 & $(0.00)$ & 0.65 & $(0.48)$ & 0.35 & $<0.001$ \\
\hline Not smoking while near children & 0.88 & $(0.33)$ & 1.00 & $(0.00)$ & 0.78 & $(0.42)$ & 0.22 & $<0.001$ \\
\hline Not smoking in community meetings & 0.58 & $(0.49)$ & 1.00 & $(0.00)$ & 0.24 & $(0.43)$ & 0.76 & $<0.001$ \\
\hline Not smoking while near pregnant women & 0.97 & $(0.16)$ & 1.00 & $(0.00)$ & 0.95 & $(0.21)$ & 0.05 & 0.037 \\
\hline Not smoking near non-smoker & 0.74 & $(0.44)$ & 0.98 & $(0.15)$ & 0.56 & $(0.50)$ & 0.42 & $<0.001$ \\
\hline
\end{tabular}

SD: standard deviation, $\mathrm{n}$ : sample size. The mean and SD values are proportions. 
among non-smokers, the corresponding percentages were $56 \%$ and $60 \%$. The mean differences of those indicators were mostly statistically significant, except for the house having a front-door ashtray.

\section{DISCUSSION}

This research is different from previous work conducted in Yogyakarta city in terms of the focus on males of whom many are smokers and SFH activities. In Bantul, the activities included: showing educational videos on the dangers of smoking during the initial meeting with the fathers, screening of blood pressure and blood glucose for awareness, and installation of an ashtray in front of the house. The evaluation of the smoke-free home program was carried out after one year of program implementation to find out changes in the smoking pattern.

The proportion of smokers among adult males in Karet hamlet (55\%) was similar to that in Indonesia $(56 \%)$ in $2018^{17}$. This is because smoking is culturally acceptable in this community. However, people in the hamlet have the characteristic of being easy to receive new knowledge that is considered beneficial so that when the SFH initiative was introduced, the reception was welcoming. Even smokers supported the SFH initiative because they were aware of the dangers for their loved ones ${ }^{12}$. This is indicated by the relatively small (19\%) proportion of smokers who smoked near family members in the hamlet compared, for instance, with Bantul district with $68 \%{ }^{17}$. This is similar to the SFH initiative in Yogyakarta city that showed SFH implementation changed the community smoking pattern by an increase in the number of smokers who smoked outdoors, from $11 \%$ at the beginning of the intervention to $54 \%$ after the program ${ }^{15}$. SFH supports the national tobacco control, especially in Bantul, per Regent Regulation 18/2016 on Healthy Areas Smoke-Free that includes houses ${ }^{18}$.

\section{Limitations}

This study has limitations, including that the preliminary evaluation was carried out simultaneously with the implementation so that success in quitting smoking is not causally related.

\section{CONCLUSIONS}

While the preliminary evaluation of the $\mathrm{SFH}$ initiative shows promising results, more political and resource support are needed from the local and national policymakers. Further research (e.g. quasiexperimental impact evaluation) is needed to assess the impact of the SFH initiative on health behaviours and outcomes in the community.

\section{REFERENCES}

1. World Health Organization. Report on the Global Tobacco Epidemic, 2011: Warning about the Dangers of Tobacco. Geneva, Switzerland: World Health Organization; 2011. https://apps.who.int/iris/bitstream/ handle/10665/44616/9789240687813_eng.pdf; jsessionid $=562134 \mathrm{FFE} 4513 \mathrm{C} 3 \mathrm{AD} 2 \mathrm{~A} 7081 \mathrm{D} 58$ 294815? sequence=1. Accessed May 31, 2019.

2. World Health Organization. Report on the Global Tobacco Epidemic, 2017: Monitoring Tobacco Use and Prevention Policies. Geneva, Switzerland: World Health Organization; 2017. https://apps.who.int/iris/bitstream/hand le/10665/255874/9789241512824-eng.pdf?sequence=1 . Accessed May 31, 2019.

3. U.S. National Cancer Institute, World Health Organization. The Economics of Tobacco and Tobacco Control. National Cancer Institute Tobacco Control Monograph 21. NIH Publication No. 16-CA-8029A. Bethesda, MD: U.S. Department of Health and Human Services, National Institutes of Health, National Cancer Institute; and Geneva, Switzerland: World Health Organization; 2016. https://cancercontrol.cancer.gov/ $\mathrm{brp} / \mathrm{tcrb} / \mathrm{monographs} / 21 /$ docs/m21_complete.pdf. Accessed May 31, 2019.

4. Ministry of Health. [Report of Basic Health Survey Riskesdas 2018]. Jakarta: Ministry of Health; 2019.

5. World Health Organization. Factsheet 2018: Indonesia. Geneva, Switzerland: World Health Organization; 2018. https://apps.who.int/iris/bitstream/handle/10665/272673/ wntd_2018_indonesia_fs.pdf?sequence $=1$. Accessed May $31,2019$.

6. U.S. Department of Health and Human Services. The health consequences of smoking-50 years of progress: A report of the surgeon general. Atlanta, GA: U.S. Centers for Disease Control and Prevention; 2014. https://www. ncbi.nlm.nih.gov/pubmed/24455788. Accessed May 31, 2019.

7. Olasky SJ, Levy D, Moran A. Secondhand smoke and CVD in low-and middle-income countries: A case for action. Global Heart. 2012;7(2):151-160. doi:10.1016/j.gheart.2012.05.002

8. Nichter M, Padmawati S, Danardono M, Ng N, Prabandari Y, Nichter M. Reading culture from tobacco advertisements in Indonesia. Tob Control. 2009;18(2):98107. doi:10.1136/tc.2008.025809

9. Lubick N. Smoking and secondhand smoke: Global Estimate of SHS Burden. Environ Health Perspect. 
2011;119(2):A66-A69. doi:10.1289/ehp.119-a66

10. Wipfli HL, Samet JM. Second-hand smoke's worldwide disease toll. Lancet. 2011;377(9760):101-102. doi:10.1016/S0140-6736(10)61922-8

11. Messer K, Mills AL, White MM, Pierce JP. The Effect of Smoke-Free Homes on Smoking Behavior in the U.S. Am J Prev Med. 2008;35(3):210-216. doi:10.1016/j.amepre.2008.05.023

12. Kennedy RD, Ellens-Clark S, Nagge L, Douglas O, Madill C, Kaufman P. Smoke free community Housing Policy: Change in Report Smoking Behavior-Finding from waterloo Region, Canada. J Community Health. 2015;40(6):1207-1215. doi:10.1007/s10900-015-0050-0

13. Alwan N, Siddiqi K, Thomson H, Lane J, Cameron I. Can a community-based 'smoke-free homes' intervention persuade families to apply smoking restrictions at homes? J Public Health. 2011;33(1):48-54. doi:10.1093/pubmed/fdq073

14. Nichter M, Padmajam S, Nichter M, et al. Developing a smoke free homes initiative in Kerala, India. BMC Public Health. 2015;15(1):480. doi:10.1186/s12889-015-1815-1

15. Padmawati R, Prabandari Y, Istiyani T, Nichter M, Nichter M. Establishing a community-based smoke-free homes movement in Indonesia. Tob Prev Cessation. 2018;4(November):1-10. doi:10.18332/tpc/99506

16. Jatmika SE, Maulana M, Kuntoro, Martini S, Anjani BS. The Readiness of Smokers to Quit Smoking. Global Journal of Health Science. 2019;11(1):172-181. doi:10.5539/gjhs.v11n1p172

17. Ministry of Health. [Report of Basic Health Survey Riskesdas 2013: Yogyakarta Province]. Jakarta: Ministry of Health; 2013.

18. Bantul Regent. [Regulation 18/2016 on Smoke Free Area]. https://peraturan.bpk.go.id/Home/Details/24243. Accessed May 31, 2019.

\section{ACKNOWLEDGEMENTS}

We thank the village head, community leaders and the community members in Karet Village for their time spent for interview and filling in the questionnaire. We acknowledge the contribution of Enge Surabina Ketaren, Eka Sopi Suwariyanti and Afrezah as enumerators.

\section{CONFLICTS OF INTEREST}

The authors have completed and submitted the ICMJE Form for Disclosure of Potential Conflicts of Interest and none was reported.

\section{FUNDING}

Support was provided by the Center for Islamic Economics and Business, Universitas Indonesia with funding awarded by Bloomberg Philanthropies to Johns Hopkins University. The manuscript's content is solely the responsibility of the authors and does not necessarily represent the official views of Bloomberg Philanthropies or Johns Hopkins University (No.085.10/ UN2.F6.D2.LDM/HKP/2018).

PROVENANCE AND PEER REVIEW

Not commissioned; externally peer reviewed. 